\title{
PENDAMPINGAN PSIKOEDUKASI: PENGUATAN CARING \\ OLEH CAREGIVER KELUARGA TERHADAP ORANG DENGAN GANGGUAN JIWA
}

\section{PSYCHEDUCATION ASSISTANCE: STRENGTHENING CARE BY FAMILY CAREGIVER TO PEOPLE WITH MENTAL DISORDER}

\author{
Ira Kusumawaty, Yunike, Marta Pastari \\ Pendidikan Vokasional, Politeknik Kesehatan Palembang \\ Korespondensi:caby_deh@yahoo.com
}

\begin{abstract}
The family as a caregiver plays a crucial role in assisting mentally ill patients in living their daily lives. However, it is known that the role of the family is still not optimal, so psychoeducation is needed. Psychoeducation assistance is important in strengthening family caregivers when caring for family members suffering from mental disorders. This study aims to improve the knowledge and ability of families to care for family members who experience mental disorders. The quasi-experimental method, one group pre-testpost test, with psychoeducation assistance interventions consisting of 3 sessions, was carried out by visiting 32 families of sufferers at his home. Every family is visited 3 times in 3 months and the family gets counseling using audiovisual media accompanied by discussion and demonstrates how to care for people with mental disorders. Repeated video playback increases family knowledge so that they are able to identify the problem of mental disorders, indicated by increased knowledge of all respondents and it is known that family psychoeducation assistance affects the increase in family knowledge about mental disorders, with a p-value of 0.0001. An increase in the percentage of families who are able to demonstrate how to treat patients well, which initially amounted to $59.38 \%$ increased to $76.50 \%$ after family psychoeducation assistance. It can be concluded that psychoeducation assistance can improve the cognitive and psychomotor abilities of family caregivers in caring for family members who suffer from mental disorders.
\end{abstract}

Keyword: assistance, caring, family caregiver, family psychoeducation, families of people with mental disorders

\begin{abstract}
ABSTRAK
Keluarga sebagai caregiver berperan krusial dalam mendampingi penderita gangguan jiwa dalam menjalani kehdupan sehari-hari. Namun demikian, diketahui bahwa peran yang dijalani keluarga tersebut masih belum optimal, sehingga diperlukan pendampingan psikoedukasi. Pendampingan psikoedukasi menjadi penting untuk memperkuat caring pada caregiver keluarga ketika merawat anggota keluarganya yang menderita gangguan jiwa. Penelitian ini bertujuan untuk meningkatkan pengetahuan dan kemampuan keluarga dalam merawat anggota keluarganya yang mengalami gangguan
\end{abstract}


jiwa. Metode kuasi eksperimen, one group pre test-post test, dengan intervensi pendampingan psikoedukasi terdiri atas 3 sessi, dilakukan dengan mengunjungi 32 keluarga penderita di rumahnya. Setiap keluarga dikunjungi 3 kali dalam 3 bulan dan keluarga mendapatkan penyuluhan menggunakan media audiovisual disertai diskusi serta mendemonstrasikan cara merawat penderita gangguan jiwa. Pemutaran video secara berulang meningkatkan pengetahuan keluarga sehingga mereka mampu mengidentifikasi permasalahan gangguan jiwa, ditunjukkan dengan meningkatnya pengetahuan seluruh responden dan diketahui bahwa pendampingan psikoedukasi keluarga berpengaruh terhadap peningkatan pengetahuan keluarga tentang gangguan jiwa, dengan $\mathrm{p}$ value 0.0001 . Terjadi peningkatan prosentase keluarga yang mampu mendemonstrasikan cara merawat penderita dengan baik, yang semula berjumlah 59,38\% meningkat menjadi 76,50\% setelah pendampingan psikoedukasi keluarga. Dapat disimpulkan bahwa pendampingan psikoedukasi dapat meningkatkan kemampuan kognitif dan psikomotor caregiver keluarga dalam merawat anggota keluarganya yang menderita gangguan jiwa. Kata Kunci: Caring, Caregiver keluarga, pendampingan, psikoedukasi keluarga,
keluarga orang dengan gangguan jiwa

\section{PENDAHULUAN}

Badan kesehatan dunia telah merilis bahwa satu diantara empat penduduk telah terjangkit gangguan neurologis. Bahkan informasi selanjutnya menyebutkan hampir 450 juta penduduk dunia mengalami gangguan jiwa, diperburuk lagi dengan fakta hampir 1 juta penduduk berperilaku bunuh diri (WHO, 2014).

$$
\text { Depresi dan kecemasan }
$$

mendominasi gangguan mental emosional di Indonesia, sekitar 6\% atau 14 juta penduduk (Riskesdas, 2013), dengan penderita skizofrenia sekitar 1,7 diantara 1000 penduduk. Selanjutnya hasil Riset Kesehatan Dasar atau
Riskesdas yang dilaksanakan pada tahun 2018, terjadi peningkatan jumlah penderita skizofrenia, yaitu menjadi 6,7 per mil pada level nasional, sedangkan di Sumatera Selatan, jumlah penderita skizofrenia berada di atas level nasional yaitu 8 per mil. Selain itu, diketahui pula bahwa hanya $35,4 \%$ penderita gangguan jiwa di Sumatera Selatan yang menjalani pengobatan secara teratur dalam 1 bulan terakhir, nampak masih berada di bawah level nasional yaitu 48,9\% (Kementerian Kesehatan, 2019). Kondisi ini yang turut memperbesar peluang terjadinya kekambuhan pada penderita skizofrenia. 
Begitu kompleks permasalahan yang dihadapi keluarga dalam merawat anggota keluarganya yang mengalami gangguan jiwa. Beban tersebut diperberat oleh adanya stigma yang dapat berasal dari diri sendiri maupun berasal dari lingkungan keluarga (Chan, Ho, \& Bressington, 2019). Kondisi tersebut memperkecil peluang terjadinya pemulihan dengan cepat (Dalky, Qandil, Natour, \& Janet, 2017). Stigma dapat memperberat kondisi penderita dan bahkan kebosanan serta kelelahan keluarga sebagai caregiver (Pérez \& Marqués, 2018).

Dukungan keluarga sangat diperlukan demi keberhasilan proses pemulihan penderita gangguan jiwa ( $\mathrm{Yu}$, Kowitt, Fisher, \& Li, 2018). Bentuk dukungan dapat dimanifestasikan dalam berbagai bentuk. Bentuk dukungan instrumental, emosional dan informasional dapat diberikan keluarga guna mempertahankan dan memperbaiki kondisi kesehatan penderita (Corrigan \& Shapiro, 2011). Dukungan tersebut merupakan bentuk caring keluarga selaku caregiver penderita. Dengan demikian maka dukungan keluarga dalam bentuk perawatan terhadap anggota keluarganya yang menderita gangguan jiwa harus optimal. Kondisi tersebut dapat terwujud melalui kemudahan mengakses pelayanan kesehatan pada level komunitas dan mengurangi stigma sebagaimana telah dicanangkan oleh WHO (Manley, 2013). Konsep ini terkait dengan pemberdayaan masyarakat, terutama anggota keluarga terdekat yang merawat penderita gangguan jiwa di rumah.

Partisipasi anggota keluarga secara aktif dapat meningkatkan kualitas hidup (Rohanah, Suyatini, 2018) merupakan inti pemberdayaan keluarga yang dilaksanakan mulai dari tahap perencanaan hingga evaluasi. Permasalahan rendahnya latar belakang pendidikan berpengaruh besar terhadap keberhasilan pemberdayaan, karena bermuara pada pengetahuan yang rendah pula. Dalam pembelajaran di komunitas, perlu diawali dengan menumbuhkan kesadaran atas permasalahan yang dialami (Sofwan \& Kuntoro, 2014). Pembelajaran pada keluarga yang tinggal bersama orang dengan gangguan jiwa (ODGJ) didukung oleh penggunaan media audiovisual (Ellen Selman et al., 2018). Edukasi pada keluarga dengan ODGJ disebut juga Psikoedukasi keluarga, merupakan salah satu program perawatan kesehatan jiwa keluarga dengan cara pemberian informasi dan 
edukasi melalui komunikasi yang terapeutik. Program psikoedukasi merupakan pendekatan yang bersifat edukasi dan pragmatic (Jorm, 2012).

Psikoedukasi keluarga dilakukan dengan cara melatih keluarga untuk mengidentifikisai gejala klinik bersama tenaga kesehatan agar mampu merencanakan perawatan bagi anggota keluarga. Melalui terapi psikoedukasi, kemampuan kognitif keluarga dapat ditingkatkan, pengetahuan keluarga tentang penyakit dan gejala penyimpangan perilaku, serta pada akhirnya diharapkan mampu meningkatkan dukungan keluarga bagi ODGJ (Chan et al., 2019). Psikoedukasi dilaksanakan melalui komunikasi yang terapeutik dan mendidik. Psikoedukasi bertujuan untuk meningkatkan pemahaman keluarga mengenai penyakit, gejala, pengobatan dan cara merawat penderita (Basirun, Thahir, \& Mawarni, 2014). Dalam merawat penderita gangguan jiwa, komunikasi menjadi faktor krusial dalam menentukan keberhasilan proses pemulihan penderita selain komponen strategi pelaksanaan perawatan yang menjelaskan teknik perawatan terhadap penderita.

\section{METODE}

Pendampingan keluarga ini bertujuan untuk meningkatkan kemampuan kelurga dalam mengenal dan memahami tentang gangguan jiwa, merencanakan tindakan yang harus dilakukan ketika muncul permasalahan serta mampu merawat penderita gangguan jiwa. Kegiatan ini merupakan usaha untuk mendukung program kesehatan jiwa pada lini masyarakat, melalui edukasi kepada keluarga. Melalui pendampingan terapi psikoedukasi, keluarga akan mampu memberikan perawatan terhadap ODGJ di rumah.

Metode kuasi eksperimen, one group pre-test post-test, dengan bentuk intervensi berupa pendampingan yang dilaksanakan pada 32 keluarga. Penentuan responden didasarkan atas teknik purposif sampling, dengan kriteria bahwa responden merupakan anggota keluarga yang tinggal serumah bersama penderita, memiliki hubungan kekerabatan dengan penderita, paling sering merawat penderita dan keluarga menyatakan kesediaannya sebagai responden serta mampu membaca dan menulis. Sebelum memulai penelitian, protokol penelitian ini telah dinyatakan lolos kaji etik oleh Komite Etik Penelitian Kesehatan Universitas 
Sriwijaya,

nomer

206/UN9.1.10/KKE/2019. Responden juga memperoleh penjelasan informed consent tentang keterlibatannya dalam penelitian yang selanjutnya ditandatangani setelah responden memahami penjelasan yang diberikan.

Pendampingan dalam bentuk psikoedukasi dilaksanakan di rumah keluarga penderita, selama 3 bulan. Pada bulan pertama, sebelum dilakukan pendampingan terhadap keluarga, peneliti terlebih dahulu mengukur pengetahuan keluarga tentang gangguan jiwa dan cara merawat anggota keluarganya yang menderita gangguan jiwa. Setelah itu keluarga diminta untuk mendemonstrasikan cara merawat penderita gangguan jiwa, hal ini dilakukan untuk mengetahui secara langsung kemampuan keluarga ketika merawat penderita gangguan jiwa. Setelah dilaksanakan pengukuran dan observasi, peneliti memberikan psikoedukasi. Selanjutnya, pada bulan kedua, dilakukan kunjungan ke rumah keluarga penderita untuk mengajarkan dan mendampingi keluarga dalam menerapkan terapi psikoedukasi kembali. Pada bulan ketiga, peneliti mengunjungi keluarga untuk memberikan terapi psikoedukasi yang ketiga kalinya. Pada bulan ketiga ini, berarti keluarga telah mendapatkan pendampingan sebanyak tiga kali, dan pengetahuan dan kemampuan keluarga dalam merawat penderita gangguan jiwa kembali diukur. Jadi setiap keluarga didatangi dan didampingi sebanyak 3 kali, satu kali setiap bulannya.

Waktu kunjungan ke rumah responden disepakati terlebih dahulu bersama responden, sehingga tidak mengganggu rutinitas kegiatan responden sehari-hari. Rentang waktu ketika berkunjung ke rumah responden adalah 90-120 menit.

Adapun tahap pelaksanaan pendampingan psikoedukasi keluarga terdiri dari 3 sesi, yaitu: sesi 1, 2 dan 3 . Adapun rincian pelaksanaannya dapat diuraikan sebagai berikut:

Sesi 1: Pengkajian masalah keluarga.

Targetnya adalah mendapatkan data-data permasalahan yang aktual tentang ODGJ di lingkungan tempat tinggal dan dalam keluarga. Pada tahap ini dilaksanakan wawancara mendalam yang bertujuan untuk mengumpulkan data ataupun gejala yang dialami penderita selama berada di rumah. Setelah dilaksanakan wawancara mendalam, selanjutnya bersama responden merumuskan data- 
data yang telah terkumpul yang berhubungan dengan permasalahan gangguan jiwa yang diderita anggota keluarganya.

Sesi 2: Mengajarkan kepada keluarga cara mengidentifikasi masalah ODGJ.

Targetnya yaitu keluarga mendapatkan pengalaman belajar dalam mengidentifikasi permasalahan gangguan jiwa serta tindakan pada keluarganya yang menderita ODGJ. Pada tahap ini, dilakukan penyuluhan dengan menggunakan media audiovisual tentang cara mengidentifikasi gangguan jiwa serta tindakan yang dapat dilaksanakan keluarga.

Sesi 3: mengajarkan kepada keluarga mengenai tindakan keperawatan yang harus diberikan kepada ODGJ sesuai hasil identifikasi permasalahan.

Targetnya adalah keluarga mendapatkan pengalaman dan dapat melakukan tindakan keperawatan pada pasien sesuai dengan permasalahan yang sedang terjadi. Pada tahap ini, keluarga mempelajari cara merawat penderita gangguan jiwa yang disampaikan melalui metoda demonstrasi. Setelah itu keluarga mencoba untuk mendemonstrasikan secara berulang. Pada bulan ketiga, kembali dilakukan penilaian pengetahuan tentang gangguan jiwa, dengan menggunakan kuesioner yang juga dipergunakan saat mengukur pengetahuan sebelum pelaksanaan pendampingan psikoedukasi. Responden selanjutnya diminta untuk memperagakan kembali ketrampilan cara merawat penderita gangguan jiwa. Observasi dilakukan untuk menilai kemampuan responden dalam mendemonstrasikan ulang seluruh ketrampilan merawat penderita gangguan jiwa yang telah diajarkan sebelumnya. Komunikasi juga merupakan aktivitas yang harus dikuasai oleh keluarga ketika merawat penderita gangguan jiwa. Maka ketika dilaksanakan pendampingan pelaksanaan terapi psikoedukasi, keluarga juga diajarkan mengenai cara berkomunikasi dengan penderita.

\section{HASIL DAN PEMBAHASAN}

Adapun hasil penelitian menunjukkan bahwa karakteristik responden keluarga yang mengikuti pendampingan terapi psikoedukasi berusia antara 16-65 tahun, serta memiliki hubungan dengan ODGJ sebagai ibu, anak, suami, istri, bibi. Mayoritas responden berpendidikan sekolah dasar (70\%) dan sekolah menengah pertama (20\%) dan $10 \%$ diantaranya tidak menyelesaikan 
pendidikan dasarnya. Pada umumnya responden berpenghasilan sangat minim, karena pekerjaannya diantaranya sebagai buruh cuci, pengemudi becak, buruh panggul, pedagang kaki lima. Adapun karakteristik penderita gangguan jiwa yang tinggal bersama keluarga sebagai caregiver yaitu mereka berada pada rentang usia 17-56 tahun serta mayoritas berpendidikan sekolah dasar dan bahkan $30 \%$ diantaranya tidak menyelesaikan pendidikan dasar.

Berdasarkan hasil identifikasi awal melalui wawancara singkat, permasalahan gangguan jiwa paling sering dialami adalah halusinasi, isolasi sosial, harga diri rendah, defisit perawatan diri dan perilaku kekerasan. Berikut rinciannya dikemukakan pada tabel 1.

Tabel 1. Distribusi frekuensi gejala Orang Dengan Gangguan Jiwa

\begin{tabular}{lcc}
\hline Gejala & Jumlah & Prosentase \\
\hline $\begin{array}{l}\text { Defisit } \\
\text { Perawatan } \\
\text { Diri }\end{array}$ & 3 & $10 \%$ \\
\hline Halusinasi & 12 & $37 \%$ \\
\hline $\begin{array}{l}\text { Isolasi } \\
\text { Sosial }\end{array}$ & 10 & $31 \%$ \\
\hline $\begin{array}{l}\text { Perilaku } \\
\text { Kekerasan }\end{array}$ & 2 & $6 \%$ \\
\hline $\begin{array}{l}\text { Harga } \\
\text { Diri } \\
\text { Rendah }\end{array}$ & 5 & $16 \%$ \\
\hline Jumlah & $\mathbf{3 2}$ & $\mathbf{1 0 0 \%}$ \\
\hline & &
\end{tabular}

Adapun rata-rata skor pengetahuan keluarga mengenai gangguan jiwa, skor minimum dan maksimum yang diraih responden, pada saat sebelum dan setelah pendampingan psikoedukasi diilustrasikan pada tabel 2 .

Tabel 2. Distribusi frekuensi perbandingan rata-rata skor pengetahuan responden sebelum dan setelah pendampingan

\begin{tabular}{cccccc}
\hline Group & Mean & SD & Min & Max & $\begin{array}{c}\text { p- } \\
\text { value }\end{array}$ \\
\hline Sebelum & 14.75 & 1.901 & 11 & 18 & 0.0001 \\
\hline Sesudah & 16.59 & 1.898 & 13 & 20 & \\
\hline
\end{tabular}

Pengukuran pengetahuan keluarga penderita tentang gangguan jiwa meliputi: gejala, keluhan, aktivitas sehari-hari, permasalahan dan tindakan yang dilakukan oleh keluarga. Data hasil analisis univariat kemudian dianalisis kembali dengan menggunakan dependen paired t test untuk mengetahui pengaruh pendampingan terhadap pengetahuan keluarga. Sebelum dilakukan analisis data penilaian pre dan post, kedua data tersebut diuji terlebih dahulu dengan menggunakan uji normalitas data. Setelah dilakukan uji normalitas, diketahui bahwa data penilaian sebelum (pre) dan sesudah (post) terdistribusi normal, karena berdasarkan uji shapiroWilk, saat pre-test, diperoleh p-value 0,057 (lebih besar dari 0,05), begitu juga p-value post-test adalah 0,93 (lebih besar 
dari 0,05). Selanjutnya dilakukan uji paired t test dan mengacu pada hasil uji tersebut diperoleh p-value yaitu 0,0001 , sehingga dapat disimpulkan bahwa pendampingan keluarga dalam bentuk penyuluhan tentang intervensi keperawatan pada pasien ODGJ berpengaruh terhadap peningkatan pengetahuan keluarga dalam mengenal gangguan jiwa dan memberikan perawatan terhadap ODGJ. Terbukti bahwa penyuluhan menggunakan media audiovisual dapat membantu dalam meningkatkan pengetahuan keluarga selaku caregiver.

$$
\text { Berikut ini tabel }
$$

menggambarkan prosentase kemampuan psikomotor responden yang sudah dapat memperagakan cara merawat penderita sebelum dilakukan demonstrasi. Pengukuran pada tahap ini hanya sebatas pengukuran distribusi frekuensi kemampuan keluarga dalam merawat saja mengingat peneliti tidak secara langsung melihat perilaku keluarga sehari-hari saat merawat penderita.

Tabel 3. Distribusi frekuensi keluarga yang mampu merawat penderita dengan benar sebelum dilakukan demonstrasi

\begin{tabular}{lcc}
\hline Komponen & Jumlah & Prosentase \\
\hline Komunikasi & 20 & $62.5 \%$ \\
\hline $\begin{array}{l}\text { Strategi } \\
\text { pelaksanaan }\end{array}$ & 18 & $56.25 \%$ \\
\hline Rata-rata & & $59.38 \%$ \\
\hline
\end{tabular}

Berdasarkan tabel 3 tampak bahwa ternyata dari 32 keluarga yang diukur kemampuannya dalam berkomunikasi terhadap penderita, baru $62.5 \%$ responden yang dapat berkomunikasi dengan baik. Mayoritas responden mengalami kesulitan ketika harus berhadapan dan berinteraksi dengan penderita, terutama ketika harus berinteraksi dengan penderita yang mengisolasi dirinya.

Tabel 4 Distribusi frekuensi keluarga yang mampu merawat penderita dengan benar setelah dilakukan demonstrasi.

\begin{tabular}{lcc}
\hline Komponen & Jumlah & Prosentase \\
\hline Komunikasi & 27 & $84 \%$ \\
Strategi pelaksanaan & 23 & $69 \%$ \\
\hline Rata-rata & & $76.5 \%$ \\
\hline
\end{tabular}

Lebih dari $75 \%$ responden sudah mampu mendemonstrasikan cara merawat penderita gangguan jiwa dengan benar. Tabel 3 dan tabel 4 memperlihatkan peningkatan jumlah keluarga dalam merawat anggota keluarganya yang menderita gangguan jiwa. Kemampuan psikomotor responden dinilai pada saat responden memperagakan cara merawat penderita. Terdapat dua komponen yang diobservasi yaitu kemampuan responden saat berkomunikasi yang ditampilkan saat berinteraksi dengan penderita, serta kemampuan mendemonstrasikan ketika 
menerapkan strategi pelaksanaan terhadap penderita. Strategi pelaksanaan saat merawat penderita halusinasi akan berbeda dengan penderita yang berperilaku kekerasan ataupun yang mengisolasi dirinya. Pada kegiatan ini, keluarga memperoleh informasi dan diajarkan cara merawat penderita sesuai strategi pelaksanaan berdasarkan permasalahan kasus penderita.

\section{Karakteristik responden}

Jika memperhatikan latar belakang pendidikan responden, maka nampak bahwa keluarga hanya memperoleh sedikit kesempatan untuk dapat bekerja dan memperoleh penghasilan yang layak. Konsekuensi tersebut muncul saat ternyata memang mayoritas penduduk bekerja sebagai buruh, yang penghasilannya sangat minim. Bahkan untuk memenuhi kebutuhan sandang dan pangan saja juga menjadi hal yang sulit untuk dipenuh secara layak. Bahkan berdasarkan hasil pengumpulan data diketahui bahwa beberapa keluarga bekerja sebagai buruh cuci pakaian di beberapa tempat guna memenuhi kebutuhan hidupnya. Kondisi itu turut mewarnai ketika akan mencari kesepakatan dalam menentukan waktu pelaksanaan pendampingan. Mayoritas keluarga hanya dapat ditemui pada siang dan sore hari, mengingat kesibukannya untuk mencari penghasilan.

Adapun karakteristik penderita gangguan jiwa yang tinggal bersama keluarga sebagai caregiver, berada pada rentang usia 17-56 tahun. Mayoritas berpendidikan sekolah dasar dan bahkan $30 \%$ diantaranya tidak menyelesaikan pendidikan dasar. Nampak bahwa halusinasi paling banyak diderita, diikuti dengan isolasi sosial. Halusinasi terjadi ketika penderita nampak berbicara atau tersenyum sendiri tanpa ada stimulus di sekitarnya. Penderita nampak sedang berbicara dengan seseorang, padahal tidak ada orang di sekitar yang mengajaknya berbicara. Keluarga lebih mudah mengenal tanda halusinasi sebagai gejala yang paling sering terjadi pada penderita skizofrenia. Diantara halusinasi yang sering terjadi pada skizofrenia adalah kasus halusinasi pendengaran (Suryani, Komariah, \& Karlin, 2014). Walaupun pendidikan responden mayoritas adalah sekolah dasar, namun bukan merupakan hal yang sulit untuk dapat mengenali gejala halusinasi. Responden dapat menceritakan perilaku yang ditampilkan oleh penderita ketika halusinasinya muncul. 
Adapun isolasi sosial nampak ketika penderita lebih menyukai untuk selalu menyendiri, tidak ada keinginan untuk bersosialisasi ataupun berinteraksi dengan orang lain. Isolasi sosial sebagai gejala terbanyak kedua dalam kegiatan ini, juga mudah untuk dikenali. Penderita yang selalu menyendiri dan tidak memiliki keinginan untuk berinteraksi dengan orang lain, mengindikasikan terjadinya isolasi sosial (Dalky, 2017). Pada saat kunjungan ke rumah keluarga, nampak penderita sering berada dalam keadaan duduk di sudut ruangan dan tidak memiliki keberanian untuk memperlihatkan wajahnya. Menundukkan kepala selalu dilakukan penderita saat berhadapan dengan orang lain dan ketika diajukan pertanyaan. Gejala gangguan jiwa lain yang nampak adalah perilaku kekerasan, namun gangguan ini tidak banyak terjadi dalam konteks ini. Penderita sering marahmarah, meluapkan kekesalannya, kemarahannya dengan cara membentak orang di sekitarnya. Bahkan ketika berada dalam kondisi marah, penderita tidak segan untuk menghancurkan barang-barang yang berada di sekitarnya. Penderita tidak lagi menghiraukan keselamatan dirinya maupun orang di sekitarnya.
Harga diri rendah ditemukan sebanyak 5\%, yang sebenarnya saling berkaitan dengan isolasi sosial, karena saling berkaitan satu sama lainnya. Harga diri rendah dapat mengakibatkan penderita mengisolasi dirinya, menutup dirinya untuk berinteraksi dengan orang lain. Pengalaman masa kecil, pola asuh berkontribusi erat terhadap munculnya berbagai kondisi gangguan kejiwaan (Kertchok, Yunibhand, \& Chaiyawat, 2011)

Pengaruh pendampingan

\section{Psikoedukasi}

Adanya berbedaan hasil pengukuran pengetahuan dan perilaku yang ditampilkan juga dapat dipengaruhi oleh kebiasaan responden sehari-hari. Kebiasaan responden dalam berkomunikasi merupakan komponen yang tidak mudah untuk diubah. Padahal komunikasi merupakan alat terpenting ketika berinteraksi selama merawat penderita gangguan jiwa. Keberhasilan dalam merawat penderita, tergantung pada kemampuan caregiver sebagai pihak yang merawatnya dalam berinteraksi melalui ketrampilan berkomunikasinya (Weinmann \& Koesters, 2016; O’Shay-Wallace, 2019). Komunikasi seseorang dipelajari sejak 
kecil dan dipengaruhi oleh pola asuh dalam keluarga, sehingga dipelajari selama bertahun-tahun, baik dalam lingkup keluarga maupun dalam lingkup yang lebih besar. Apalagi jika penderita sudah terdiagnosa gangguan jiwa kronis dan pernah mengalami kekambuhan, maka rasa jenuh dan beban berat keluarga telah dirasakan keluarga selama bertahun-tahun. Kebosanan dan rasa jenuh keluarga tentunya sangat berpengaruh terhadap kesabaran keluarga dalam merawat penderita. Hal ini secara langsung berimplikasi terhadap bentuk komunikasi yang ditampilkannya ketika harus berinteraksi dengan penderita. Belum lagi beban stigma yang tidak hanya dialami penderita namun juga menimpa keluarga (Singh, Mattoo, \& Grover, 2016).

Stigma memberikan beban tersendiri tidak hanya bagi penderita, namun juga bagi keluarga. Kondisi tersebut memperberat beban yang telah ditanggung sebelumnya. Rasa malu, merasa berbeda dari orang lain merupakan penderitaan yang sulit untuk dianggap sebagai hal yang biasa saja. Sebagian besar responden yang hanya berlatar belakang pendidikan sekolah dasar juga turut membebani kondisi psikososial keluarga, disamping jenis pekerjaan yang mereka geluti turut mempersulit mereka dalam meluangkan waktu bersama penderita. Dalam hal ini, akibat pendidikan yang rendah berdampak terhadap jenis pekerjaannya, sehingga keluarga harus bekerja di beberapa tempat, misalnya sebagai buruh cuci untuk menambahkan penghasilan agar kebutuhan keluarga dapat terpenuhi. Hal ini tentunya mengurangi waktu kebersamaan keluarga dengan penderita, sehingga pada situasi nyata, penderita lebih banyak tidak berinteraksi dengan orang lain selama berada di rumah. Penderita lebih banyak menyendiri, merenung dan tidak melaksanakan aktivitas apa pun. Dalam penerapan psikoedukasi, keluarga diajarkan agar selalu berinteraksi bersama penderita dan memberikan kesempatan kepada mereka untuk melaksanakan aktivitas tertentu untuk menumbuhkan dan meningkatkan kepercayaan diri penderita.

Berdasarkan hasil penelitian yang telah dikemukakan sebelumnya, beberapa hal yang perlu dibahas yaitu bahwa pemberdayaan keluarga merupakan usaha untuk mendukung program kesehatan jiwa pada lini masyarakat, melalui edukasi kepada keluarga, diharapkan masyarakat 
khususnya keluarga dapat mendukung perawatan ODGJ di rumah (Janardhana et al., 2015). Pemberdayaan keluarga akan dapat memampukan keluarga untuk mengatasi permasalahannya dengan cara yang benar. Proses pemberdayaan tentunya harus dilaksanakan secara bertahap, agar keluarga dapat menjalaninya dengan nyaman dan tidak merasa terpaksa. Bagaimanapun juga memberdayakan keluarga dalam merawat penderita gangguan jiwa bukan hal yang mudah, walaupun keluarga telah menyadari peran mereka sebagai caregiver.

Keluarga merupakan sumber sistem pendukung utama bagi penderita gangguan jiwa di rumah, bentuk dukungan keluarga keluarga sangat mempengaruhi program penyembuhan penderita gangguan jiwa. Keluarga merupakan sistem pendukung utama bagi pasien sehingga keluarga berhak untuk memperoleh informasi secara adekuat mengenai berbagai hal tentang gangguan jiwa yang mendera anggota keluarganya (Chan, 2011). Sebagaimana telah disampaikan sebelumnya, bahwa bentuk dukungan keluarga dapat berupa dukungan instrumental, emosional dan informasional. Dapat dijelaskan lebih lanjut, ada kemungkinan antara satu bentuk dukungan dengan bentuk dukungan yang lain ditemukan adanya saling keterkaitan. Jika keluarga tidak memiliki informasi yang memadai tentang cara merawat gangguan jiwa ataupun cara berkomunikasi dengan baik terhadap penderita, maka keluarga akan mengalami kesulitan dalam mengatur emosinya, ataupun kondisi psikologisnya ketika berinteraksi dengan penderita yang berada dalam kondisi kambuh. Demikian juga jika pemahaman keluarga kurang adekuat, maka keluarga memiliki keterbatasan dalam menyediakan fasilitas yang diperlukan oleh penderita dalam menjalani kehidupannya seharihari dengan benar, sesuai kondisi penderita dan tidak mengganggu masyarakat di sekitarnya. Dengan demikian maka tenaga kesehatan memiliki kewajiban untuk memberikan informasi kepada keluarga untuk membekali keluarga dalam merawat penderita di rumah sehingga menumbuhkan kepercayaan diri mereka.

$$
\text { Sebagaimana penelitian }
$$
terdahulu menyebutkan bahwa stigma membebani keluarga dan stigma ini dapat berasal dari lingkungan sekitar, jika stigma dapat diminimalisir, maka dapat meningkatkan kepercayaan diri dalam merawat penderita (Corrigan, 
Druss, \& Perlick, 2014). Pentingnya menumbuhkan kepercayaan diri keluarga dalam merawat berdampak terhadap keberhasilan proses pemulihan penderita dan mencegah terjadinya kekambuhan.

Pemberian edukasi pada keluarga ODGJ bukan hanya untuk menumbuhkan kepercayaan diri keluarga dalam merawat, namun juga bertujuan agar keluarga tidak menganggap bahwa kehadiran masalah gangguan kejiwaan dalam keluarga sebagai beban dan stressor. Kehadiran stressor dapat memicu depresi bagi keluarga (Bonanno \& Burton, 2013) sehingga menyebabkan pemberian perawatan pada ODGJ tidak maksimal, mengingat bahwa keluarga merupakan pemberi perawatan utama yang terdekat dan sering berinteraksi dengan ODGJ. Keluarga merupakan pihak yang paling mengetahui kondisi atau pun karakter penderita, sehingga memiliki potensi dalam mengurangi dan meringankan beban psikososial yang dialami penderita melalui psikoedukasi.

$$
\text { Psikoedukasi keluarga adalah }
$$

suatu metoda berdasarkan pada penemuan klinis untuk melatih keluarga mengidentifikasi, merencanakan bentuk perawatan berdasarkan arahan tenaga profesional. Kemampuan kognitif keluarga dapat ditingkatkan melalui psikoedukasi keluarga karena dalam terapi tersebut mengandung unsur untuk meningkatkan pengetahuan keluarga tentang penyakit, mengajarkan tehnik yang dapat membantu keluarga untuk mengetahui gejala-gejala penyimpangan perilaku, serta peningkatan dukungan bagi ODGJ. Hal ini menunjukkan besarnya dampak dukungan keluarga pagi penderita (Shi et al., 2019). Dampak positif psikoedukasi keluarga adalah untuk mencegah terjadinya kekambuhan penderita (Basirun et al., 2014; Shiraishi et al., 2019) dan juga mempercepat proses pemulihan penderita (Sharif et al., 2016). Keluarga yang telah dapat memahami pentingnya psikoedukasi, akan tetap berusaha untuk secara konsisten menerapkannya dalam kehidupan sehari-hari. Kesadaran akan pentingnya menerapkan psikoedukasi yang dapat mengurangi permasalahan psikososial penderita, akan semakin memotivasi keluarga dalam mengupayakan

mengimplementasikannya secara sungguh-sungguh. Dengan terbantukannya penyelesaian masalah psikososial penderita maka beban keluarga atas kehadiran penderita yang memerlukan bimbingannya pun menjadi semakin ringan. 
Pendampingan psikoedukasi keluarga diperlukan agar keluarga dapat menentukan permasalahan yang sedang dihadapinya terkait ODGJ yang dirawatnya. Melalui pendampingan, keluarga menentukan tindakan atau cara merawat yang harus diakukan oleh keluarga di rumah. Dukungan keluarga sebagai sistem pendukung berpeluang besar dalam mencegah terjadinya kekambuhan. Kekambuhan penderita gangguan jiwa, merupakan fenomena yang seringkali terjadi dan hal ini mengakibatkan kejenuhan keluarga. Belum lagi jika terjadi perubahan perilaku penderita secara tiba-tiba dan tidak dapat diprediksi. Perilaku kekerasan misalnya, mengakibatkan kelelahan yang luar biasa bagi keluarga yang merawatnya, selain risiko atas keselamatannya menjadi terancam, baik mengancam diri penderita, keluarga ataupun masyarakat di sekitarnya (Gharavi et al., 2018; Goldberg et al, 2019).

Hasil penelitian ini menunjukkan adanya peningkatan pengetahuan dan kemampuan merawat penderita berkaitan dengan banyak hal. Faktor pertama adalah bentuk demonstrasi yang disampaikan tentang cara merawat ODGJ, kedua, yaitu faktor responden yang melihat dan mempelajari cara merawat. Usia respon yang beragam, tingkat pendidikan yang mayoritas adalah sekolah dasar, turut menentukan keberhasilan responden untuk memperagakan kembali perilaku cara merawat ODGJ. Namun tentunya perilaku yang ditampilkan juga dapat dipengaruhi oleh pemahaman atau pengetahuan responden. Semakin baik pengetahuan keluarga, maka akan semakin baik pula cara keluarga merawat yang akan dilakukannya terhadap penderita (Chan, 2011).

Namun demikian, tidak dapat dipungkiri bahwa diperlukan motivasi yang kuat dari keluarga dalam merawat penderita sesuai psikoedukasi yang telah diberikan agar permasalahan penderita dapat diminimalisir dan penderita dapat beradaptasi dengan baik. Kemampuan penderita untuk dapat menyesuaikan diri atau beradaptasi dengan baik tentunya akan mengurangi kemungkinan terjadinya kekambuhan penderita. Memupuk motivasi, menyegarkan kembali pemahaman keluarga akan pentingnya merawat dengan benar perlu untuk dilakukan terus-menerus, bukan hanya bagi anggota keluarga tertentu saja yang merupakan caregiver, namun juga anggota masyarakat lainnya agar 
menjadi lebih memahami kondisi serta penderitaan ODGJ dan keluarganya. Dukungan yang diberikan masyarakat dapat mereduksi stigma yang dirasakan penderita dan keluarga, sehingga menumbuhkan kepercayaan diri bahwa mereka juga dapat memberikan manfaat bagi masyarakat sekitar.

\section{SIMPULAN}

Pendampingan terapi psikoedukasi sangat bermanfaat dalam meningkatkan perilaku caring keluarga selaku caregiver penderita gangguan jiwa. Diperlukan pendekatan perawat yang baik agar menumbuhkan kepercayaan keluarga terhadap perawat agar dapat mengungkapkan permasalahan yang dihadapinya. Keterbukaan keluarga akan mempermudah perawat dalam memberikan pendampingan psikoedukasi. Kemampuan kognitif serta psikomotor keluarga dapat ditingkat melalui pendampingan psikoedukasi, dengan demikian secara langsung dapat meningkatkan caring keluarga saat merawat anggota keluarganya yang menderita gangguan jiwa. Keluarga sebagai lingkungan utama penderita diharapkan mampu memberikan bantuan yang mendukung pemulihan kondisi psikososial penderita.

\section{UCAPAN TERIMA KASIH}

Penghargaan serta ucapan terima kasih disampaikan kepada Politeknik Kesehatan Palembang yang telah memberikan dukungan sehingga penelitian ini dapat terlaksana sesuai perencanaan.

\section{DAFTAR PUSTAKA}

Basirun, S., Thahir, A., \& Mawarni, A. (2014). Journal of Psychology and Psychotherapy Family Psychoeducation: Effect of Enhancing the Knowledge of Controlling Violent Behavior of People with Schizophrenia Pilot Study, (18), 1-6. https://doi.org/10.35248/21610487.19.9.360

Bonanno, G. a., \& Burton, C. L. (2013). Regulatory Flexibility: An Individual Differences Perspective on Coping and Emotion Regulation. Perspectives on Psychological Science, 8(6), 591-612. https://doi.org/10.1177/1745691613 504116

Chan, S. W. (2011). Global Perspective of Burden of Family Caregivers for Persons With Schizophrenia. Archives of Psychiatric Nursing, 25(5), 339-349. https://doi.org/10.1016/j.apnu.2011. 03.008

Chan, S. Y. Y., Ho, G. W. K., \& Bressington, D. (2019). Experiences of self-stigmatization and parenting in Chinese mothers with severe mental illness. International Journal of Mental Health Nursing, 28(2), 527-537. https://doi.org/10.1111/inm.12558 
Corrigan, P. W., Druss, B. G., \& Perlick, D. A. (2014). The Impact of Mental Illness Stigma on Seeking and Participating in Mental Health Care. Psychological Science in the Public Interest, 15(2), 37-70. https://doi.org/10.1177/1529100614 531398

Corrigan, P. W., \& Shapiro, J. (2011). Stigma of Mental Illness. Clinical Psychology Review, 30(8), 907922.

https://doi.org/10.1016/j.cpr.2010.0 6.004.Measuring

Dalky, H. F., Qandil, A. M., Natour, A. S., \& Janet, M. C. (2017). Quality of Life, Stigma and Burden Perception Among Family Caregivers and Patients with Psychiatric Illnesses in Jordan. Community Mental Health Journal, 53(3), 266-274. https://doi.org/10.1007/s10597-0160028-0

Ellen Selman, L., Fox, F., Aabe, N., Turner, K., Rai, D., \& Redwood, S. (2018). "You are labelled by your children"s disability'-A community-based, participatory study of stigma among Somali parents of children with autism living in the United Kingdom. Ethnicity and Health, 23(7), 781796.

https://doi.org/10.1080/13557858.2 017.1294663

Gharavi, Y., Stringer, B., Hoogendoorn, A., Boogaarts, J., Van Raaij, B., \& Van Meijel, B. (2018). Evaluation of an interaction-skills training for reducing the burden of family caregivers of patients with severe mental illness: A pre-posttest design. BMC Psychiatry, 18(1), 18. https://doi.org/10.1186/s12888018-1669-Z

Goldberg, Z. E., Chin, N. P., Alio, A., Williams, G., \& Morse, D. S.
(2019). A Qualitative Analysis of Family Dynamics and Motivation in Sessions With 15 Women in Drug Treatment Court. Substance Abuse: Research and Treatment, 13, $\quad 117822181881884$. https://doi.org/10.1177/1178221818 818846

Janardhana, N., Raghunandan, S., Naidu, D., Saraswathi, L., \& Seshan, V. (2015). Care giving of people with severe mental illness: An Indian experience. Indian Journal of Psychological Medicine, 37(2), 184. https://doi.org/10.4103/02537176.155619

Jorm, A. F. (2012). Mental health literacy; empowering the community to take action for better mental health. American Psychologist, 67(3), 231-243. https://doi.org/10.1037/a0025957

Kementerian Kesehatan. (2018). Potret sehat indonesia dari riskesdas 2018.

Kertchok, R., Yunibhand, J., \& Chaiyawat, W. (2011). Creating a new whole: Helping families of people with schizophrenia. International Journal of Mental Health Nursing, 20(1), 38-46. https://doi.org/10.1111/j.14470349.2010.00706.x

Link, B. G., Struening, E. L., NeeseTodd, S., Asmussen, S., \& Phelan, J. C. (2001). The Consequences of Stigma for the Self-Esteem of People With Mental Illnesses. Psychiatric Services, 52(12), 16211626.

https://doi.org/10.1176/appi.ps.52.1 2.1621

Manley, G. (2013). Public Access NIH Public Access, 71(2), 233-236. https://doi.org/10.1038/mp.2011.18 2.doi

Min, J. A., Lee, C. U., \& Lee, C. (2013). Mental health promotion and illness prevention: A challenge for 
psychiatrists. Psychiatry Investigation, 10(4), 307-316. https://doi.org/10.4306/pi.2013.10.4 .307

O'Shay-Wallace, S. (2019). "We Weren't Raised that Way": Using Stigma Management Communication Theory to Understand How Families Manage the Stigma of Substance Abuse. Health Communication, O(0), 1-10. https://doi.org/10.1080/10410236.2 019.1567443

Pérez, J. J. N., \& Marqués, Á. C. (2018). Family burden, social support and community health in caregivers of people with serious mental disorder. Revista Da Escola de Enfermagem Da U S P, 52, e03351. https://doi.org/10.1590/S1980220X2017029403351

Rohanah, Suyatini. (2018). Kualitas hidup lansia di Kelurahan Karangsari Tangerang tahun 2017. Jurnal Medikes. 5(2). p 168-173.

Sharif, F., Mahmoudi, A., Alavi Shooshtari, A., \& Vossoughi, M. (2016). The effect of familycentered psycho-education on mental health and quality of life of families of adolescents with bipolar mood disorder: A randomized controlled clinical trial. International Journal of Community Based Nursing and Midwifery, 4(3), 229-238.

Shi, Y., Shao, Y., Li, H., Wang, S., Ying, J., Zhang, M., ... Sun, J. (2019). Correlates of affiliate stigma among family caregivers of people with mental illness: A systematic review and metaanalysis. Journal of Psychiatric and Mental Health Nursing, 26(1-2), 49-61.

https://doi.org/10.1111/jpm.12505

Shiraishi, N., Watanabe, N., Katsuki, F., Sakaguchi, H., \& Akechi, T.
(2019). Effectiveness of the Japanese standard family psychoeducation on the mental health of caregivers of young adults with schizophrenia: A randomised controlled trial. BMC Psychiatry, 19(1), $1-12$. https://doi.org/10.1186/s12888-0192252-y

Singh, A., Mattoo, S., \& Grover, S. (2016). Stigma and its correlates in patients with schizophrenia attending a general hospital psychiatric unit. Indian Journal of Psychiatry, 58(3), 291. https://doi.org/10.4103/00195545.192024

Suryani, Komariah, M., \& Karlin, W. (2014). Familie's perception towards schizophrenia. Padjadjaran Nursing Journal, 2(2), 124-132.

Tsang, H. W. H., Ching, S. C., Tang, K. H., Lam, H. T., Law, P. Y. Y., \& Wan, C. N. (2016). Therapeutic intervention for internalized stigma of severe mental illness: A systematic review and metaanalysis. Schizophrenia Research, 173(1-2), 45-53. https://doi.org/10.1016/j.schres.201 6.02.013

Weinmann, S., \& Koesters, M. (2016). Mental health service provision in low and middle-income countries: Recent developments. Current Opinion in Psychiatry, 29(4), 270275.

https://doi.org/10.1097/YCO.00000 00000000256

World Health Organization. (2014). Promoting Mental Health: Concepts, emerging evidence, practice. Geneva.

Yildirim, Z., Ertem, D. H., Ceyhan Dirican, A., \& Baybas, S. (2019). Who is the bigger stigmatizor?: The loved one or the society. Epilepsy and Behavior, 96, 13-22. 
https://doi.org/10.1016/j.yebeh.201 9.04.013

Yu, S., Kowitt, S. D., Fisher, E. B., \& Li, G. (2018). Mental Health in China: Stigma, Family Obligations, and the Potential of Peer Support. Community Mental Health Journal, 54(6), https://doi.org/10.1007/s10597-017-

0182-Z 